\title{
HERITABILITY OF TEAT SHAPE AND TEAT END SHAPE IN CATTLE
}

\author{
L. LOJDA, M. ŠTAVÍKOVA, J. POLÁČEK \\ Veterinary Research Institute, 62132 Brno
}

Received March 24, 1982

\begin{abstract}
Lojda L., M. Stavíková, J. Poláček.: Heritability of Teat Shape and Teat End Shape in Cattle. Acta vet. Brno, 51, 1982: 59-67.

Heritability of teat shape and teat end shape was studied in Bohemian Pied cows. Teat shape was evaluated by visual inspection and on the basis of indices $I_{1}$ and $I_{2}$ proposed in this study. The coefficients of heritability of the two indices computed from the regression of daughter on dam in 185 dam-daughter pairs were $0.380 \pm 0.08$ and $0.354 \pm 0.08$, respectively. The coefficient of heritability of teat end shape computed from the dam-daughter regression was $0.414 \pm 0.17$, but the coefficient of heritability of this characteristic computed by means of the intraclass correlation coefficient in groups of paternal half sisters sired by 30 bulls was only 0.085 . Fourteen pairs of dizygotic twins were included in the study to investigate their concordance with regard to teat shape and teat end shape. Half of the pairs of twins both had all 4 teats of equal shape; 3, 2 and 1 equally shaped teats were found in 3, 1 and 1 pairs, respectively, and two pairs were completely discordant. The concordance of twins with regard to teat end shape was also considerable: 78.5 per cent of the pairs both had 4,3 or at least 2 teats with equally shaped ends and only 2 pairs were completely discordant. Where the dams of the twins were available for comparison, their teat and teat end shapes agreed with those of one of their daughters at least.
\end{abstract}

Cattle, heritability, teat shape, teat end shape, mastitis.

Since the present approach to bovine mastitis control, based mainly on therapy and preventive measures, has apparently failed to meet the expectations, it will be necessary to combat the disease simultaneously from several angles.

In a previous study from our laboratory (Lojda et al. 1972) a significant relationship was found between udder health and some morphological characteristics of the teat. The present study was designed to investigate the involvement of genotype in the general variability of these traits.

Although occasional references to the inheritance of udder and teat shape and their anomalies have been made since the 1930's, Fisher claimed in 1953 that very little has been done for improvement of the morphological characteristics of the mammary gland. Since the 1950's, however, the possibility of improving these morphological and functional characteristics by selection has received increasing attention (Witt 1951; Winzenried 1954; Hecker 1955; Dachs 1958; Comberg et al. 1964; a. o.). Of particular interest are the observations of Hoefliger (1952), Johansson and Korckmann (1952) and Liebenberg and Jannermann (1957) on the role of bulls in the inheritance of the characteristics of the udder.

Rostkowski (1954) found a small udder with short teats and very poor milkability in 37 daughters from different cows mated to the same bull. Butz and Schmahlstieg (1955) described the incidence of hypoplasia of the mammary gland in 12 sisters and 15 daughters of one bull.

Machts (1958), on the other hand, described the incidence of the same teat anomaly in daughters of a cow mated to different bulls and regarded it as a case of inheritance with incomplete dominance. The heritability of teat length, diameter and placement was studied by Groot (1951), Rostkowski (1954), Sommer et al. (1961), Mácha et al. (1974) a. o. Some investigators con- 
cluded that teat lenght is more heritable than teat diameter, but others failed to support this view.

Brodauf (1963) described the incidence of bottle-shaped teats in front quarters of 6 out of 12 cows sired by the same bull, but only in one of their daughters sired by another bull, and suggested that this anomaly was inherited as a simple autosomal recessive characteristic.

Liebke (1954) was the first to investigate the mode of inheritance of the shape of teat ends. He reported that 25.2 per cent of the cows under study had plate-shaped or inverted funnel-shaped teat ends. He also studied the progeny of a bull whose rudimentary teats had inverted funnel-shaped ends and found this teat end shape in the majority of his daughters. He suggested that this characteristic was inherited as a dominant gene with incomplete penetrance. This hypothesis of the mechanism of teat and inheritance was questioned by Johanss on (1957) who reported that 11 out of 22 pairs of monozygotic twins both had the same teat end shapes in all 4 teats, 8 pairs in some teats and only 3 pairs were discordant. He also found that teats with plate-shaped teat ends predispose to teat orifice eversion and, in consequence, to mastitis. Similar conclusions were reached in our laboratory (Lojda et al. 1972). Another study from our laboratory was concerned with the heritability of teat shape and teat end shape (Lojda et al. 1975).

\section{Materials and Methods}

The heritability of teat shape and teat end shape was studied in 1200 Bohemian Pied cows on different farms in the South-Moravian region. Morphological characteristics of a total of 2407 teats were assessed by visual inspection, measurement and photography. Only lactating cows from the second lactation onwards, i.e. animals whose udder was fully developed, were included in the study. Puerperant and dry cows were not included in view of possible changes in teat length and diameter during lactation. The measurement consisted of measuring teat length and teat diameter at 3 levels: at the base of the teat, in the middle and $1.5 \mathrm{~cm}$ from the teat apex. The measuring instrument was a device specially modified for this purpose.

Teat shape was assessed by visual inspection in combination with computation of two indices, $I_{1}$ and $I_{2}$, proposed for this purpose in the present study (Fig. 1).

Index $I_{1}$ is given by the following relation:

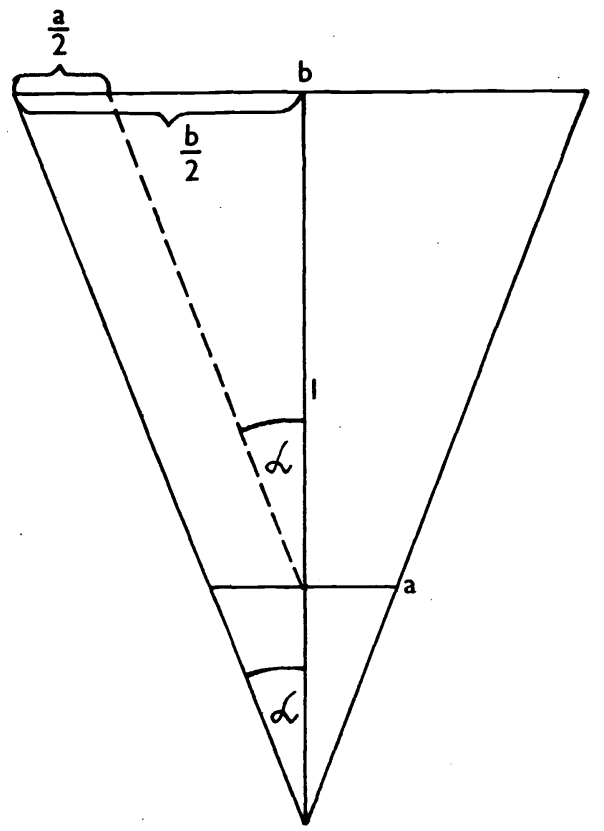

Fig. 1.

A drawing showing the parameters used in the computation of index $I^{1}$.

$$
I_{1}=\operatorname{tg} \alpha=\frac{x}{1}=\frac{\frac{1}{2}(a-b)}{1}=\frac{b-a}{21}
$$

where $b=$ teat diameter at the base

$a=$ teat diameter $1.5 \mathrm{~cm}$ from the apex

1 = teat length

$x=\frac{1}{2}(b-a)$ (see Fig. 1).

Index $I_{1}$ is therefore the tangent (tg) of the angle formed by teat axis with the line connecting the end points of the teat diameters at the base and at the apex. Index $I_{1}$ makes it possible to differentiate with certainty between cylindrical shape teats, on the one hand, and funnel shape and bottle shape teats, on the other hand, since in cylindrical shape teats the tg $\rightarrow 0$ whereas in the remaining two teat shapes the $\operatorname{tg} \neq 0$. The mean $I_{1}$ values for the three teat forms in the population under study were as follows:

cylindrical shape teats: $I_{1}=0.084 \pm 0.02$

bottle shape teats: $\quad I_{1}=0.150 \pm 0.04$

funnel shape teats: $\quad I_{1}=0.160 \pm 0.04$

Statistical analysis by means of Student's t-test revealed highly significant $(P<0.01)$ differences between cylindrical and bottle- 
-shaped teats as well as highly significant differences $(P<0.01)$ between cylindrical and funnel-shaped teats. No significant differences, however, were found between bottle-shaped and funnel-shaped teats. To differentiate between these two teat forms, another index, $I_{2}$, was employed. This index is given by the following relation:

$$
I_{2}=\frac{m}{a}
$$

where $m=$ teat diameter in the middle of the teat

$a=$ teat diameter $1.5 \mathrm{~cm}$ from the apex

The mean $I_{2}$ values for the two teat forms in the population under study were as follows:

bottle shape teats: $I_{2}=1.35 \pm 0.05$

funnel shape teats: $I_{2}=1.50 \pm 0.05$

The indices $I_{1}$ and $I_{2}$ permit a reliable classification of traits into the three teat shape groups. The heritability of the indices was estimated from the regression of daughter on dam in 185 dam-daughter pairs. According to Fews on (1965) the regression coefficient, $b_{y / x}$, is given by the relation

$$
b_{y / x}=\frac{\Sigma x y-\frac{\Sigma x \Sigma y}{n}}{\Sigma x^{2}-\frac{(\Sigma x)^{2}}{n}}
$$

with a standard error $s_{b / x}=\frac{1}{\sqrt{n}}$.

Since the degree of relatedness between parents and offspring is given by the coefficient $1 / 2$, it is necessary to multiply the regression coefficient by two to obtain the coefficient of heritability $\left(h^{2}\right)$. Accordingly, $h^{2}=2 b_{y / x}$ with a standard error $\mathrm{s}_{h} 2=\frac{2}{\sqrt{n}}$.

Fourteen pairs of dizygotic twins were included in the study to investigate their concordance with regard to teat shape and teat end shape. The shapes of teat ends were classified into three basic groups (round, plate-shaped and pointed) on the basis of visual inspection. The heritability of teat end shape was estimated from the dam-daughter regression in 185 dam-daughter pairs. Moreover, the coefficient of heritability was computed by means of the intraclass correlation coefficient $\hat{(\varrho)}$ obtained by analysis of variance in groups of paternal half sisters sired by 30 bulls.

\section{Results and Discussion}

The coefficients of heritability of teat shape indices $\mathrm{I}_{1}$ and $\mathrm{II}_{2}$ were $0.380 \pm$ \pm 0.08 and $0.354 \pm 0.08$, respectively.

The concordance of twins with regard to teat shape was considerable. Half of the 14 pairs of twins both had all 4 teats of equal shape; 3, 2 and 1 equally shaped teats were found in 3,1 and 1 pairs, respectively, and two pairs were completely discordant. Where the dams of the twins were available to us for comparison, their teat and teat end shapes agreed with those of one of their daughters at least. Fig. 2-4 illustrate the genetic influence of the dam on teat shape and teat end shape in the twins. The results were not evaluated statistically because of the small numbers of animals.

The coefficient of heritability of teat end shape computed from the groups of paternal half sisters was very low $\left(h^{2}=0.085\right)$. Nevertheless, it cannot be concluded that this characteristic is poorly inherited. Presumably it was the effect of different environmental conditions that came into play, since the groups of half sisters were raised on several farms differing in milking and management practices. The inheritance of plate-shaped teat end, e.g., is illustrated by the same 


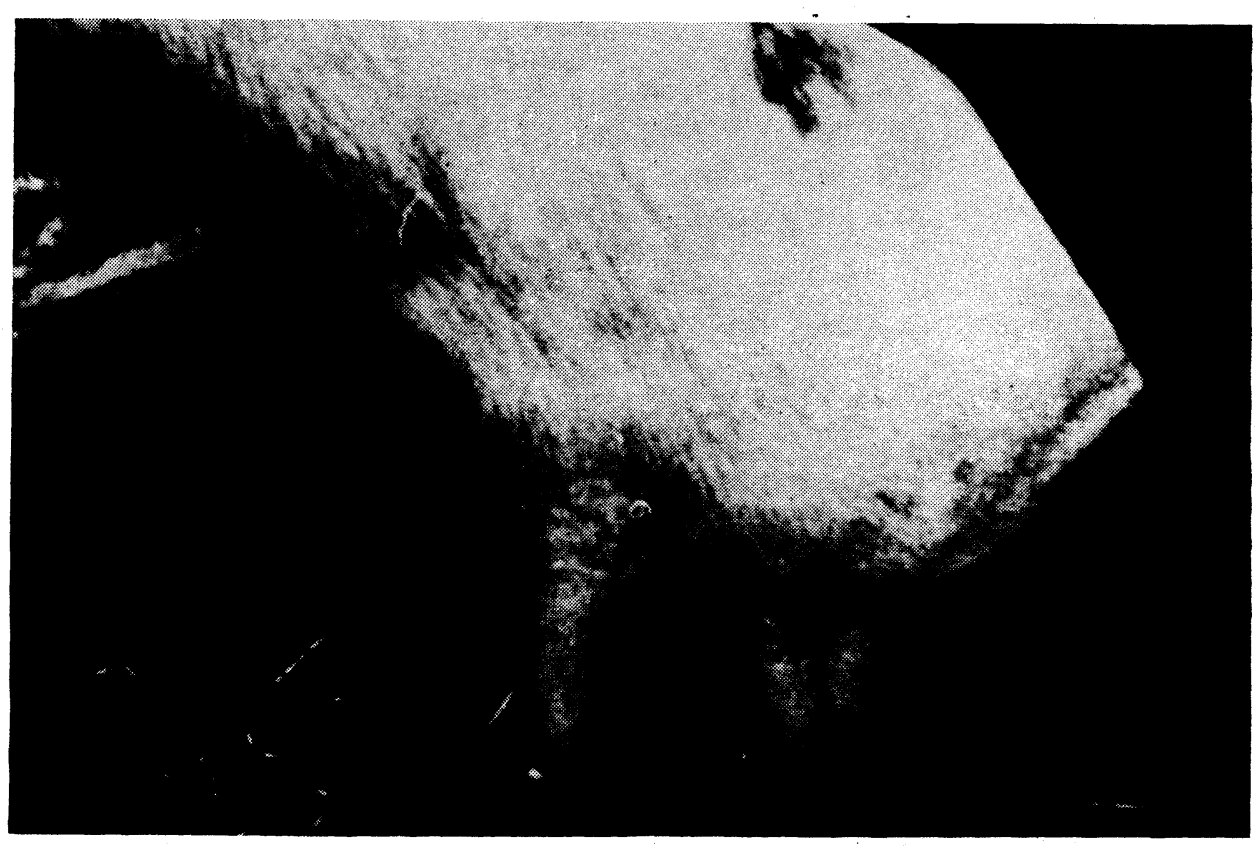

Fig. 2

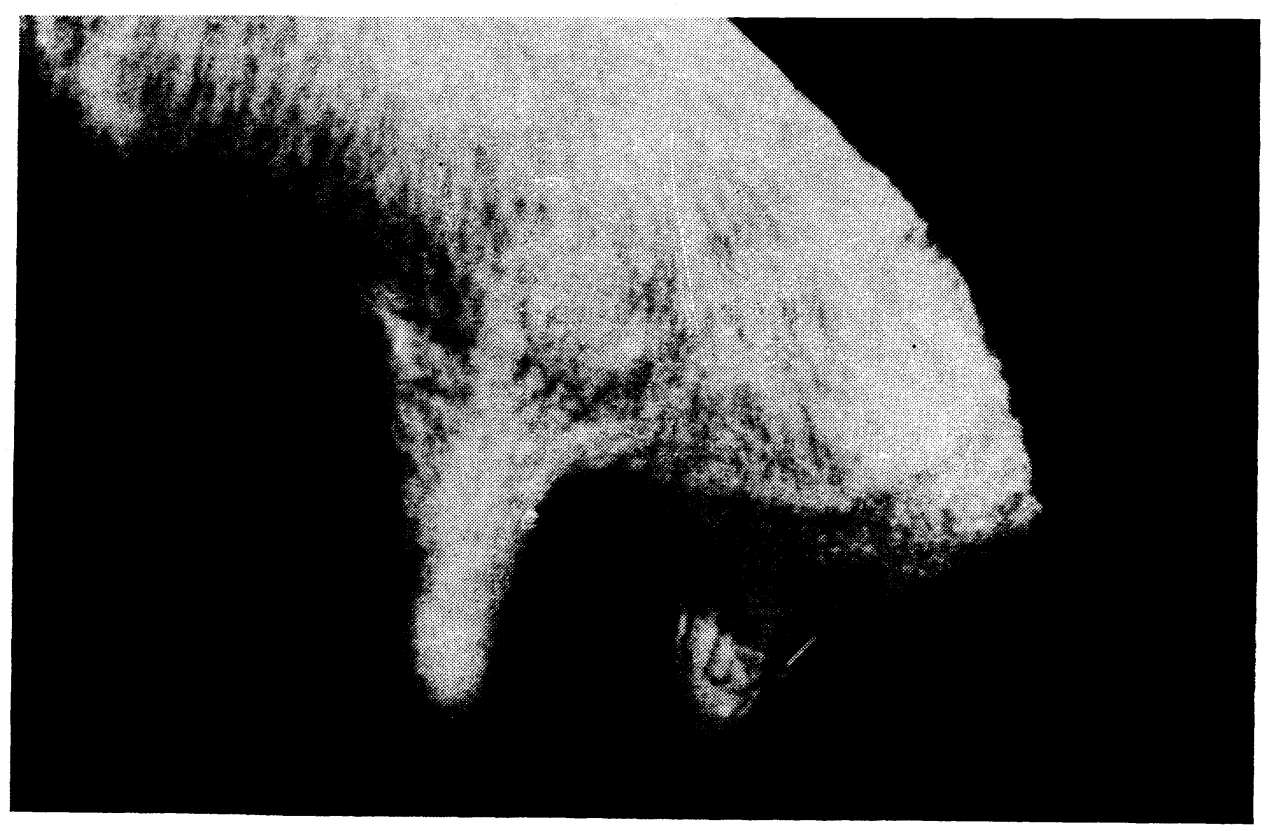

Fig. 3 
findings in the dam, daughter and granddaughter in Fig. 5-7. On the other hand, the coefficient of heritability computed from the dam-daughter regression was as high as $0.414 \pm 0.17$. and seems to reflect the actual state, since the dams and daughters were kept, for the most part, in the same environment. In twins, where the situation was analogous, the concordance with regard to teat end shape was also considerable: 78.5 per cent of the pairs had 4,3 or at least 2 teats with equally shaped ends. As in teat shape, differences in teat end shape were found only in two pairs of twins. It must be remembered that not only the dam, but also the sire plays a role in the inheritance of this characteristic as was pointed out by Liebke (1954) and was confirmed by our findings in bulls where rudimentary teats could be classified as to teat end shape.

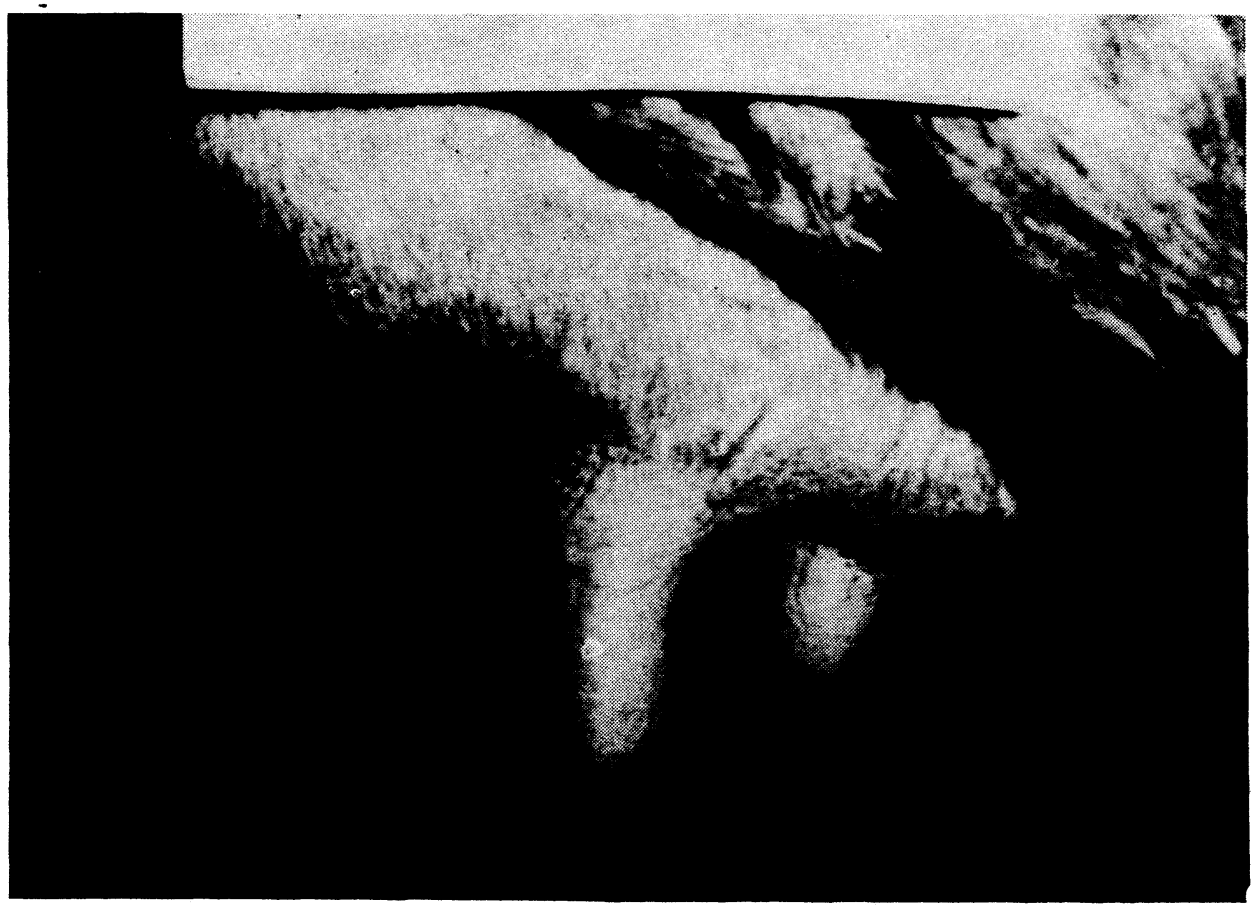

Fig. 2-4.

Involvement of genotype in the shape of the udder and teats (dam - daughters)

Fig. 2, dam; Fig. 3 and 4 - twin daughters.

Our findings of teat end shape in twins are in keeping with those reported by Johansson (1957) who found the same teat end shape of all four teats in 50 per cent of the pairs, a considerable concordance in 30 per cent of the pairs, and approximately the same proportion of discordant pairs as in our study. Moreover, it should be kept in mind that Johanss on (1957) made his study on monozygotic twins. Nevertheless, the concordance of dizygotic twins and their dams with regard to teat and teat end shape in our study was fairly high.

The results reported here suggest that genotype plays a major role in both teat shape and teat end shape. Practical implications of this observation with 


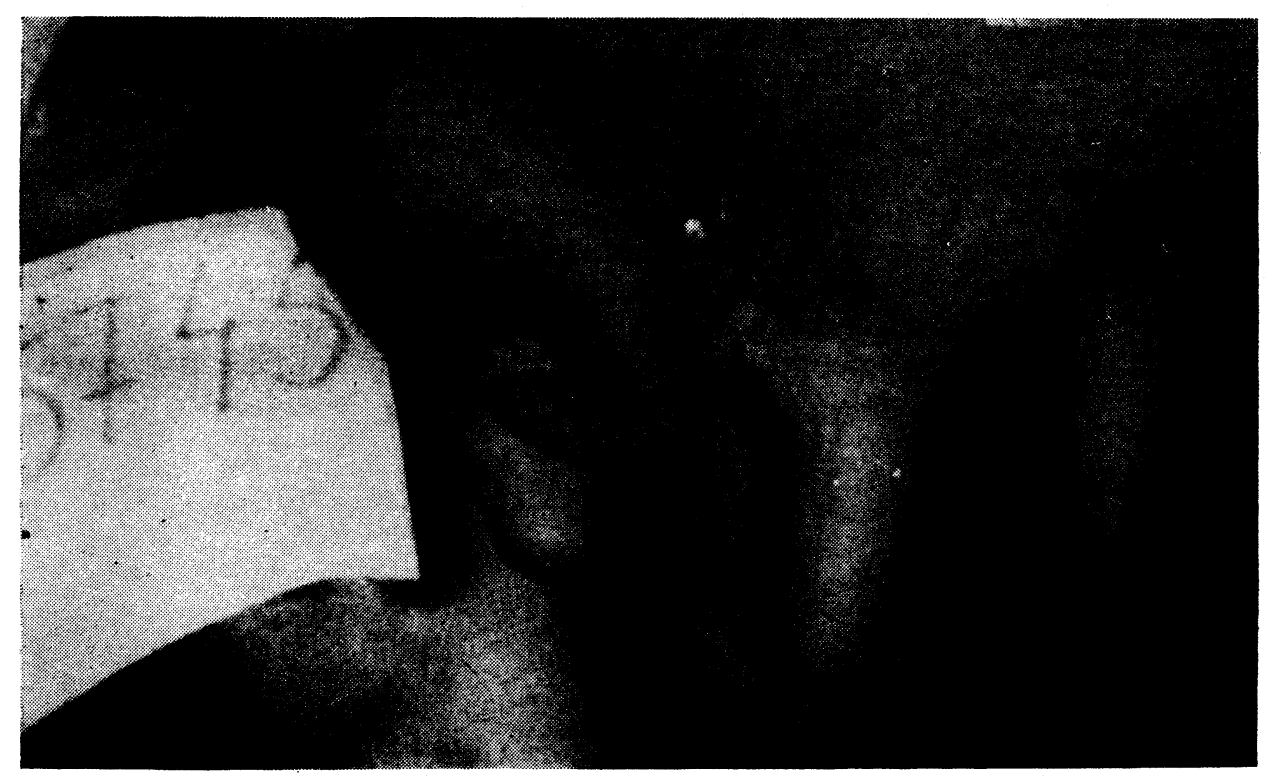

Fig. 5

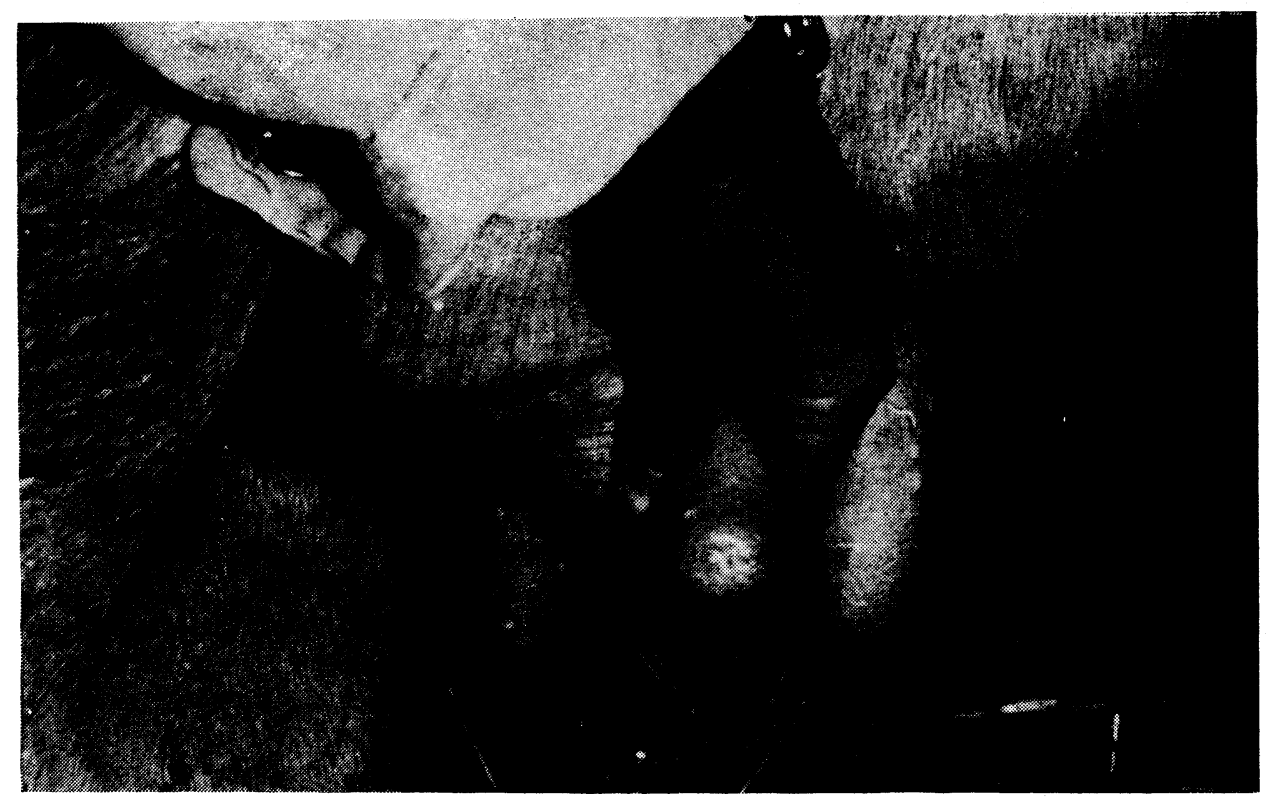

Fig. 6 


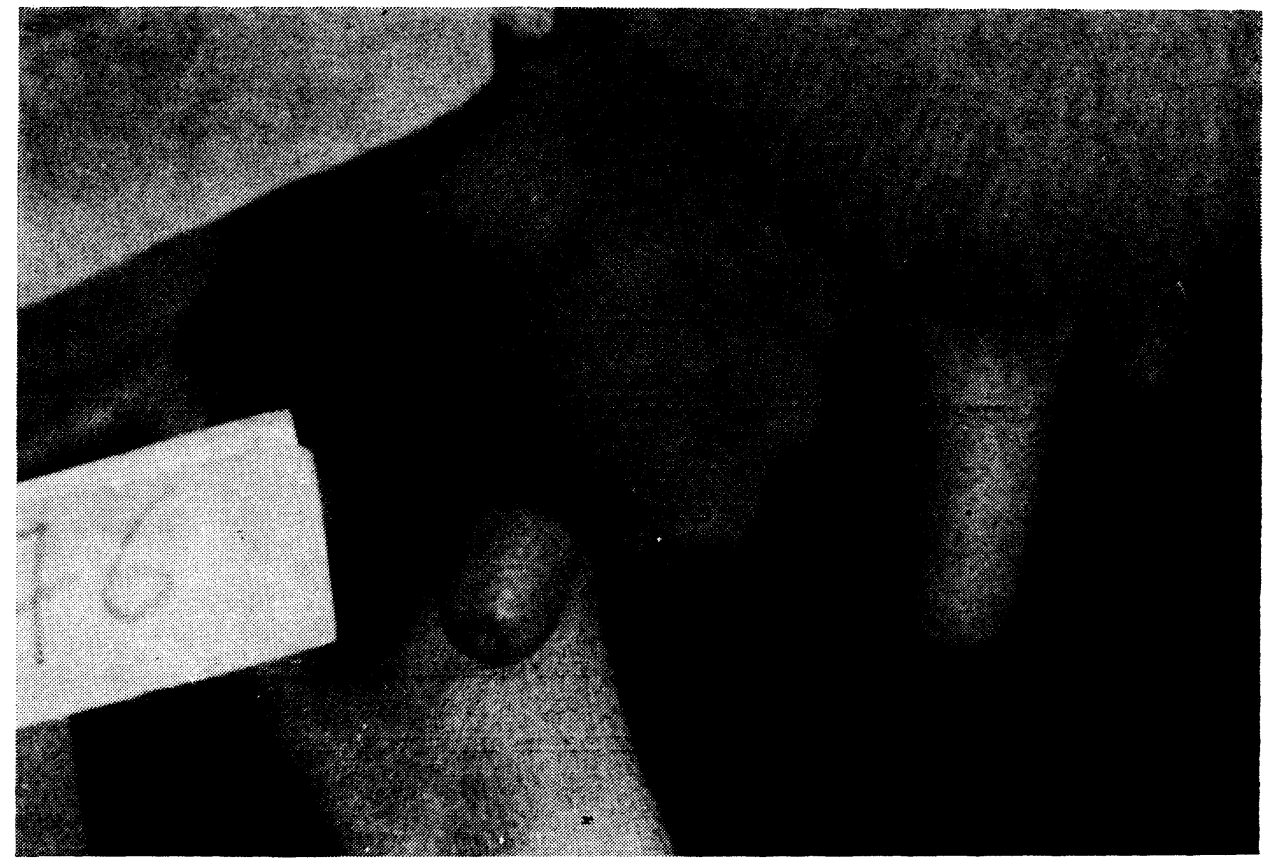

Fig. 5-7.

Inheritance of teat end shape (dam - daughter - granddaughter)

Fig. 5, dam; Fig. 6, daughter; Fig. 7, granddaughter.

regard to mastitis prevention are obvious: teat end shapes predisposing to mastitis should be eliminated from bovine herds by selection. Since sires, too, are known to be involved in the transmission of teat end shape, this characteristic should receive due attention in the dams of future breeding bulls.

\section{Studie dědivosti tvaru a zakončení struku skotu}

Byla studována dědivost tvaru a zakončení struku u dojnic českého strakatého plemena.

Koeficient heritability indexů charakterizujících tvar struku a vypočítaný $\mathrm{z}$ regresního vztahu 185 dvojic dcera-matka byl:

pro $I_{1}$ (index) $h^{2}=0,380 \pm 0,08$

pro $I_{2} \quad \mathrm{~h}^{2}=0,354 \pm 0,08$

Odhad heritability zakončení struku, získaný stejnou metodou, dosáhl hodnoty $h^{2}=0,414 \pm 0,17$. Avšak koeficient heritability vypočítaný pomocí intrakorelačního koeficientu a skupin polosester po 30 býcích byl velmi nízký $\left(h^{2}=0,085\right)$. U 14 párů dizygotních dvojčat byla sledována konkordance těchže morfologických vlastností strukủ a jejich zakončení. $50 \%$ dvojčat mělo úplně shodný tvar všech struků, dalších $21 \%$ se shodovalo ve 3 strucích a $7 \%$ ve dvou. Naprostá diskor- 
dance tvaru byla zjištěna pouze $\mathrm{u}$ dvou párů. Výsledky sledování shody $\mathrm{v}$ zakončení struku byly obdobné. Konkordance byla u 78,5 \% př́ípadů, ovšem někdy pouze $u$ tř̌ech, výjimečně $u$ dvou struků, předních nebo zadních. Diskordantní zakončení všech strukủ měly pouze dva páry dvojčat. Pokud byly srovnávány $s$ dvojčaty i jejich matky, byla shoda tvaru i zakončení strukủ minimálně alespoň $s$ jednou dcerou.

\section{Изучение наследуемости формы и окончания соска крупного рогатого скота}

Проводились изучения наследуемости формы и окончания соска дойных коров племени чешская пеструшка.

КоэфФициент наследуемости индексов, характеризующих форму соска и рассчитанный из регрессивного отношения 185 пар дочь - мать достигал:

для $I_{1}$ (индекс) $h^{2}=0,380 \pm 0,08$

для $I_{2} \quad h^{2}=0,354 \pm \cup, 38$

Оценка наследуемости оокнчания соска, полученная одинаковым методом, достигла величины $h^{2}=0,414 \pm 0,17$. Однако, коэффициент наследуемости, рассчитанный с помощью коэффициента интракорреляции у групп полусестер после 30 быков, был весьма низок $\left(h^{2}=0,085\right)$. У 14 пар двияйцевых двоен исследовалась согласованность тех же морфологических свойств сосков и их окончания. $50 \%$ двоен отличалось полностью совпадающей формой всех сосков, следующие $21 \%$ - совпадали 3 соска и у $7 \%$ два соска. Совершенное расхождение формы было установлено лишь у двух пар. Результаты исследований совпадения окончания соска были тождественны. Совпадение наблюдалось в $78,5 \%$ случаев, однако, иногда лишь у трех, в исключительном порядке у двух передних или задних сосков. Расхождение окончания всех сосков было установлено лишь у двух пар двоен. При сравнении двоен с их матерями совпадение формы и окончания сосков было установлено хотя бы с одной дочерью.

\section{Acknowledgement}

The authors wish to thank RNDr. Olga Matoušková of the Veterinary Research Institute, Brno, for statistical analysis of the results.

\section{References}

BRODAUF, H.: Über die Vererbung der Milch bzw. Zisternenbruchs des Rindes. Zuchthyg. FortpflStörung. Besamung. 7, 1963: 43-47.

BUTZ, H. - SCHMAHLSTIEG, R.: Erblicher Milchmangel als Folge einer Hypoplasie des Drüsenpar enchyms mit formal und kausaler Analyse. Dte tierärztl. Wschr., 62, 1955: 463-467.

COMBERG, G. - BAUDITZ, J. - MÚLLER, W.: Die Ausformung der vorderen Euterhälfte unter dem Blickwinkel der Forderungen von Melkmaschineneinsatz und Arbeitswirtschaft. Züchtungskunde, 36, 1964: 145-158.

DACHS, W.: Untersuchungen über Form und Größe des Euters als Grundlage der Beuteilung. Z. Tierzücht. Zücht-Biol., 72, 1958: 1-32.

FEWSON, D.: Haustiergenetik, Hohenheím 1965.

FISCHER, H.: Genetische Betrachtungen über Anomalien der Milchdrüse des Rindes. Berl. Münch. tierärztl. Wschr., 66, 1953: 381-383. 
GROOT, TH.: Over te dicht bij elkaar geplaatste spenen. Tijdschr. Diergeneeesk., 76, 1951: $448-451$.

HECKER, E.: Forderungen an das Euter aus den Erfahrungen beim Hand- und Maschinenmelken. Züchtungskunde, 27, 1955: 220-235.

HOEFLIGER, H.: Über Drüsenaplasie in Eutervierteln des Rindes. Schweizer Arch. Tierheilk., 94, 1952: $347-355$.

JOHANSSON, I. - KORKAMNN, N.: Heritability of the udder proportions in dairy cows. Hereditas, 38, 1952: 113-125.

JOHANSSON, I.: Untersuchungen über die Variation in der Euter- und Strichform der Kühe. Z. Tierzücht. ZüichtBiol., 70, 1957: 233-270.

LIEBENBERG, O. - JANNERMANN, J.: Über die züchterische Beeinflussung von Euterform und -größe. Tierzucht. 11, 1957: 45-47.

LIEBKE, H. Úber die Erblichkeit von Euteranomalien unter besonderer Berücksichtigung der Teller- und Trichter zitzen. Diss. Berlin 1954. $49 \mathrm{pp}$.

LOJDA, L. - ŠT̃AVÍKOVÁ, M. - MATOUŠKOVÁ, O. et. al.: Studium morfologických a funkčních úchylek mléčné žlázy skotu ve vztahu $k$ jejich genetické podmíněnosti a $k$ onemocnění mléčné žlázy. Project report, Brno, Veterinary Research Institute.

LOJDA, L. - ŠTTAVIKOVÁ, M. - INGR, I. - RUBEŠ, J.: Dědivost některých morfologických a funkčních úchylek mléčné žlázy skotu. Project report. Brno, Veterinary Research Institute $1975.45 \mathrm{pp}$.

MÁCHA, J. - KIRSCHNEROVÁ, D. - NAVRÁTILOVÁ, H.: Dědičnost a proměnlivost tvarových vlastností vemene českého strakatého skotu. In: Zborník 7. dni genetiky hospodárskych zvierat, 1. Tatranská Lomnica 1974, p. 261.

MACHTS, K.: Eine erbliche Zitzenanomalie in einer Kuhfamilie. Zuchthyb. FortpflStörung. Besamung, 3, 1958: 300-302.

ROSTKOWSKI, S.: Ein Beitrag zur Vererbung der Zitzenform beim Rind Thesis. Berlin 1954. $100 \mathrm{pp}$.

SOMMER, A. O.: Wichtige Form- und Funktionseigenschaften des Euters unter des Berücks der Melkbarkeit. Züchtungskunde, 33, 1961: 264-267.

WINZENRIED, H. U.: Die Erblichkeit der Euterform und ihre Bedeutung für die Zuchtwahl. Schweizer Arch. Tierheilk., 96, 1954: 649-659.

WITT, M.: Das Melkmaschineneuter. Züchtungskunde, 23, 1951: 93-101. 